\title{
Towards construction of a canine linkage map: establishment of 16 linkage groups
}

\author{
F. Lingaas, ${ }^{1}$ A. Sørensen, ${ }^{1}$ R.K. Juneja, ${ }^{2}$ S. Johansson, ${ }^{2}$ M. Fredholm, ${ }^{3}$ A.K. Winter,${ }^{3}$ J. Sampson, ${ }^{4}$ C. Mellersh, ${ }^{4}$ \\ A. Curzon, ${ }^{4}$ N.G. Holmes, ${ }^{5}$ M.M. Binns, ${ }^{5}$ H.F. Dickens, ${ }^{5}$ E.J. Ryder, ${ }^{5}$ J. Gerlach, ${ }^{6}$ E. Bäumle, ${ }^{7}$ G. Dolf ${ }^{7}$ \\ ${ }^{1}$ Norwegian Kennel Klub and Department of Morphology, Genetics and Aquatic Biology, Section of Genetics, P.O. Box. 8146 Dep., N-0033 \\ Oslo, Norway \\ ${ }^{2}$ Department of Animal Breeding and Genetics, Swedish University of Agricultural Sciences, Box 7023, 75007 Uppsala, Sweden \\ ${ }^{3}$ Department of Animal Science and Animal Health, Division of Animal Genetics, The Royal Veterinary and Agricultural University, Bülowsvej, 13, \\ DK-1870, Fredriksberg C, Copenhagen, Denmark \\ ${ }^{4}$ The Department of Biochemistry, University of Leicester, University Road, Leicester, LE1 7RH, UK \\ ${ }^{5}$ Centre for Preventive Medicine, Animal Health Trust, PO Box 5, Newmarket, Suffolk CB8 7DW, UK \\ ${ }^{6}$ Medical Technology and Medicine, Michigan State University, B228 Life Science, East Lansing, Michigan 48824-1317, USA \\ ${ }^{7}$ Institute of Animal Breeding, University of Berne, Bremgartenstrasse 109 a, 3012 Berne, Switzerland
}

Received: 3 September 1996 / Accepted: 15 November 1996

Over the last few years great efforts have been put into the genetic and physical mapping of several mammalian species. Among mammals, human and mouse maps are the most developed, but significant progress has also been made in economically important agricultural species like cattle, sheep, and pig. Microsatellite loci have formed the basis of these genetic maps because they display significant polymorphism and are evenly distributed throughout the genome. An international collaboration (DogMap) was established in 1993, with the initial aim of generating a low-resolution canine marker map. Details about the aims, participants, rules, etc. of DogMap can be found on the WWW at http://ubeclu.unibe.ch/ itz/dogmap.hrml. One important long-term objective of the work is to establish tools to identify the gene(s) responsible for inherited disease, thereby offering the possibility to develop strategies that could reduce the incidence of such diseases through systematic selective breeding.

The combination of genetic mapping with the physical assignment of the markers to specific chromosomes has been successful for most animal species with a well-developed gene map. The complex karyotype of the dog, consisting of 78 chromosomes, many of which are similar in size and banding pattern, makes physical mapping difficult. At the moment only 21 autosomes have an internationally accepted karyotype (Świtoński et al. 1996), and cytogenetic identification of canine chromosomes will probably rely on both traditional banding as well as indirect identification with specific probes, anchor loci, and chromosome paints.

This study presents a linkage analysis of 94 polymorphic loci and provides the first linkage groups from the International DogMap collaboration.

At the First International DogMap Meeting (1993) a common reference panel for typing polymorphic markers was established; this was the first such panel for canine genetic mapping. The reference panel, including the parents, consists of a total of 129 dogs of pure-bred German Shepherd (35 offspring) and Beagles (71 offspring). Details of the family structure are given in Fig. 1.

In the present study, 94 genetic markers were typed in the reference panel (Table 1). Five of the loci were protein polymorphisms, one was a tandem repeat in the von Willebrand factor gene, and the rest were microsatellites ( 3 tetranucleotide and 85 dinucleotide repeats). The five protein polymorphisms consisted of four blood plasma proteins; transferrin (TF), alpha 1 - protease

Correspondence to: F. Lingaas inhibitor (PI), alpha 1B-glycoprotein (A1BG), apolipoprotein A4 (APOA4) and erythrocyte enzyme superoxide dismutase 1 (SOD1). The number of alleles detected in the reference family varied between 2 and 11 , with a mean value of 4.8 alleles. An overview of the marker loci, number of alleles, as well as the proportion of heterozygotes in the parents, is given in Table 1.

Microsatellites were typed in five laboratories using primers radiolabeled with $[\gamma-33 \mathrm{P}]$ ATP and manual sequencing gels or fluorescently labeled primers and an automated sequencer (Phar-
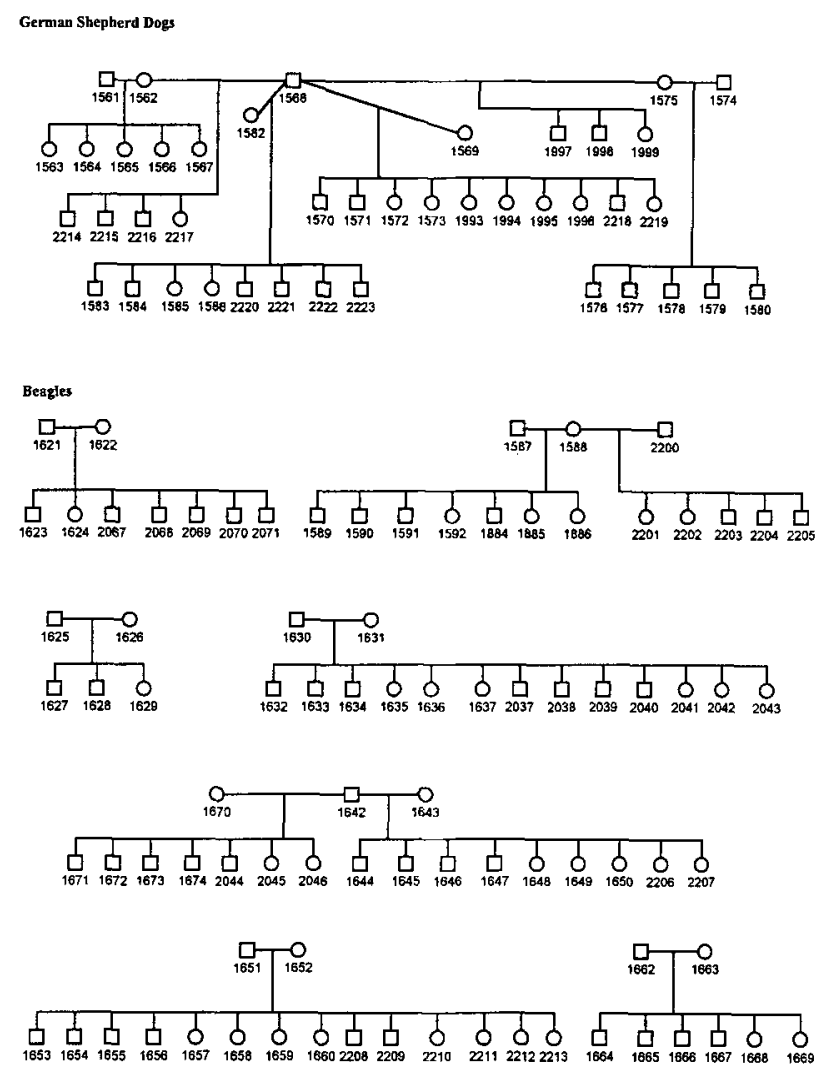

Fig. 1. Reference panel for typing polymorphic markers, consisting of a total of 129 dogs of pure-bred German Shepherd (35 offspring) and Beagles (71 offspring). 
Table 1. Overview over markers used for typing in the reference panel of DogMap.

\begin{tabular}{|c|c|c|c|}
\hline Locus & $\begin{array}{l}\text { No. of } \\
\text { alleles }\end{array}$ & $\begin{array}{l}\text { Proportion of } \\
\text { heterozygotes in } \\
\text { parents }\end{array}$ & References \\
\hline 176 & 5 & 0.522 & Ostrander et al. 1995 \\
\hline 188 & 2 & 0.261 & Ostrander et al. 1995 \\
\hline 191 & 2 & 0.348 & Ostrander et al. 1995 \\
\hline 339 & 5 & 0.696 & Ostrander et al. 1995 \\
\hline 349 & 4 & 0.652 & Ostrander et al. 1995 \\
\hline 359 & 5 & 0.739 & Ostrander et al. 1995 \\
\hline 363 & 5 & 0.348 & Ostrander et al. 1995 \\
\hline 371 & 4 & 0.783 & Ostrander et al. 1995 \\
\hline 383 & 3 & 0.783 & Ostrander et al. 1995 \\
\hline 403 & 3 & 0.522 & Ostrander et al. 1995 \\
\hline 453 & 7 & 0.565 & Ostrander et al. 1995 \\
\hline 473 & 11 & 0.870 & Ostrander et al. 1995 \\
\hline 618 & 6 & 0.565 & Ostrander et al. 1995 \\
\hline 629 & 5 & 0.348 & Ostrander et al. 1995 \\
\hline 630 & 7 & 0.522 & Ostrander et al. 1995 \\
\hline 2001 & 7 & 0.826 & Francisco et al. 1996 \\
\hline 2010 & 4 & 0.696 & Francisco et al. 1996 \\
\hline 2054 & 7 & 0.522 & Francisco et al. 1996 \\
\hline 2088 & 4 & 0.435 & Francisco et al. 1996 \\
\hline $\begin{array}{l}\text { A1BG (alpha1B- } \\
\text { glycoprotein) }\end{array}$ & 2 & 0.261 & Juneja et al. 1987 \\
\hline AHT101 & 6 & 0.522 & Holmes et al. 1993a \\
\hline AHT103 & 6 & 0.696 & Holmes et al. 1995 \\
\hline AHT104 & 2 & 0.304 & Holmes et al. 1995 \\
\hline AHT107 & 3 & 0.522 & Holmes et al. $1993 \mathrm{a}$ \\
\hline AHT109 & 3 & 0.348 & Holmes et al. $1993 a$ \\
\hline AHT110 & 3 & 0.217 & Holmes et al. $1993 \mathrm{a}$ \\
\hline AHT111 & 5 & 0.565 & Holmes et al. 1993a \\
\hline AHT115 & 2 & 0.130 & Holmes et al. $1993 \mathrm{~b}$ \\
\hline AHT118 & 5 & 0.391 & Holmes et al. 1995 \\
\hline AHT119 & 4 & 0.261 & Holmes et al. 1995 \\
\hline AHT121 & 7 & 0.826 & Holmes et al. 1995 \\
\hline АНT123 & 4 & 0.348 & Holmes et al. 1995 \\
\hline AHT125 & 6 & 0.652 & Holmes et al. 1994 \\
\hline AHT127 & 3 & 0.391 & Holmes et al. 1995 \\
\hline AHT129 & 5 & 0.609 & Unpublished \\
\hline AHT133 & 5 & 0.522 & Holmes et al. 1995 \\
\hline AHT135 & 4 & 0.565 & Unpublished \\
\hline AHT138 & 4 & 0.522 & Holmes et al. 1995 \\
\hline AHTf66 & 6 & 0.609 & Unpublished \\
\hline AHTk120 & 6 & 0.522 & Unpublished \\
\hline AHTk20 & 4 & 0.609 & Fischer et al. 1996 \\
\hline AHTk207 & 3 & 0.478 & Unpublished \\
\hline AHTk211 & 5 & 0.696 & Unpublished \\
\hline AHTk292 & 6 & 0.304 & Unpublished \\
\hline AHTk32 & 5 & 0.435 & Unpublished \\
\hline AHTk39 & 5 & 0.522 & Unpublished \\
\hline APOA4 (apolipo- & & & \\
\hline protein A4) & 2 & 0.391 & Juneja et al. 1989 \\
\hline CPH 8 & 5 & 0.435 & Fredholm and Winterø 1995 \\
\hline CPH 1 & 3 & 0.435 & Fredholm and Winterø 1995 \\
\hline CPH 10 & 7 & 0.652 & Fredholm and Winterø 1995 \\
\hline CPH 11 & 11 & 0.478 & Fredholm and Winterø 1995 \\
\hline $\mathrm{CPH} 12$ & 2 & 0.304 & Fredholm and Winterø 1995 \\
\hline CPH 13 & 8 & 0.609 & Fredholm and Winterø 1995 \\
\hline CPH 14 & 4 & 0.609 & Fredholm and Winterø 1995 \\
\hline CPH 15 & 4 & 0.435 & Fredholm and Winterø 1995 \\
\hline CPH 16 & 6 & 0.522 & Fredholm and Winterø 1995 \\
\hline CPH 19 & 6 & 0.391 & Fredholm and Winterø 1995 \\
\hline $\mathrm{CPH} 2$ & 4 & 0.565 & Fredholm and Winterø 1995 \\
\hline CPH 20 & 3 & 0.348 & Fredholm and Winterø 1995 \\
\hline $\mathrm{CPH} 21$ & 7 & 0.522 & Unpublished \\
\hline CPH 3 & 6 & 0.652 & Fredholm and Winterø 1995 \\
\hline CPH 4 & 4 & 0.304 & Fredholm and Winterø 1995 \\
\hline $\mathrm{CPH} 5$ & 3 & 0.391 & Fredholm and Winterø 1995 \\
\hline CPH 6 & 7 & 0.435 & Fredholm and Winterø 1995 \\
\hline CPH 7 & 7 & 0.522 & Fredholm and Winterø 1995 \\
\hline CPH 9 & 5 & 0.435 & Fredholm and Winterø 1995 \\
\hline CXX.123 & 6 & 0.435 & Ostrander et al. 1993 \\
\hline CXX.130 & 6 & 0.522 & Ostrander et al. 1993 \\
\hline CXX.140 & 5 & 0.522 & Ostrander et al. 1993 \\
\hline CXX.147 & 3 & 0.435 & Ostrander et al. 1993 \\
\hline CXX.176 & 5 & 0.522 & Ostrander et al. 1995 \\
\hline CXX.2 & 5 & 0.435 & Ostrander et al. 1993 \\
\hline CXX.20 & 7 & 0.696 & Ostrander et al. 1993 \\
\hline CXX.213 & 6 & 0.739 & Ostrander et al. 1993 \\
\hline CXX.250 & 6 & 0.826 & Ostrander et al. 1993 \\
\hline CXX.251 & 3 & 0.174 & Ostrander et al. 1993 \\
\hline
\end{tabular}

Table 1. Continued.

\begin{tabular}{|c|c|c|c|}
\hline Locus & $\begin{array}{l}\text { No. of } \\
\text { alleles }\end{array}$ & $\begin{array}{l}\text { Proportion of } \\
\text { heterozygotes in } \\
\text { parents }\end{array}$ & References \\
\hline CXX.279 & 6 & 0.652 & Ostrander et al. 1993 \\
\hline CXX.30 & 7 & 0.565 & Ostrander et al. 1993 \\
\hline CXX.69 & 4 & 0.609 & Ostrander et al. 1993 \\
\hline LEI 004 & 3 & 0.696 & Holmes et al. 1993a \\
\hline LEI 015 & 5 & 0.609 & Mellersh et al. 1994 \\
\hline LEI 030 & 4 & 0.739 & Unpublished \\
\hline LEIO01 & 4 & 0.652 & Holmes et al. $1993 \mathrm{a}$ \\
\hline LEIO0S & 8 & 0.826 & Unpublished \\
\hline LEI024 & 4 & 0.391 & Unpublished \\
\hline LEIO25 & 5 & 0.391 & Unpublished \\
\hline LEI028 & 3 & 0.391 & Unpublished \\
\hline LEI032 & 4 & 0.435 & Unpublished \\
\hline MichiganCO4107 & 5 & 0.696 & Yuzbasiyan-Gurkan et al., 1996 \\
\hline \multicolumn{4}{|l|}{$\begin{array}{l}\text { PI (alpha1- } \\
\text { protease }\end{array}$} \\
\hline inhibitor) & 2 & 0.087 & Juneja et al. 1987 \\
\hline \multicolumn{4}{|l|}{$\begin{array}{l}\text { SOD } 1 \\
\quad \text { (superoxide }\end{array}$} \\
\hline dismutase 1) & 2 & 0.130 & Baur and Schorr, 1969. \\
\hline TF (transferrin) & 3 & 0.348 & Juneja et al. 1987 \\
\hline VIAS-D 10 & 4 & 0.348 & Primmer and Matthews 1993 \\
\hline VWF & 3 & 0.522 & Shibuya et al., 1994 \\
\hline
\end{tabular}

macia ALF, ABI 377). Two-point linkage analysis was carried out with the computer program package FASTLINK 3.0P (Cottingham et al. 1993). As the maximum number of haplotypes is restricted in the analysis with FASTLINK, we first conducted a two-point analysis involving all 94 loci. Only then did we conduct multipoint analyses for ordering purposes exclusively, including only those loci that were linked.

Based on two-point linkage analysis, 43 of the 94 loci could be assigned to 16 different linkage groups (Table 2) which if they correspond to different chromosomes would place linkage groups on about half of the canine chromosomes. Seven linkage groups comprised more than two loci, and of these three could be ordered (Fig. 2). Three of the microsatellites genotyped have also been assigned to chromosomes by FISH. The present standard canine karyotype includes all chromosomes down to 21 ; at present, it is not possible to unambiguously resolve the smaller chromosomes. Using the physical mapping data (Fischer et al. 1996), we can assign two linkage groups to chromosomes (L13 to Canis familiaris 20 (CFA20), and L16 to CFA18); a third linkage group, L8, can be assigned as belonging to a group of the smaller chromosomes.

Assuming that the size of the haploid canine genome is approximately the same as in other mammals $(30 \mathrm{M})$ the 16 linkage groups bracket about $6.5 \%$ of the haploid genome $(1.9 \mathrm{M})$. If we further assume that our family material would allow us to detect linkage within $10 \mathrm{cM}$ of a given marker, that is, $10 \mathrm{cM}$ on either side of a linkage group and $10 \mathrm{cM}$ on either side of an unlinked marker, our 16 linkage groups together with the 51 unassigned markers, the total of the 94 investigated loci, potentially cover 15 $\mathrm{M}$, which is about $50 \%$ of the haploid genome.

The dog represents the most differentiated domesticated species in terms of the number of distinct breeds and offers many possibilities for basic genetic research not found in other species. Hundreds of years of selective breeding, cross-breeding, linebreeding and inbreeding have created dramatic phenotypic and genetic differences, and there may be fixation, or at least very high allele frequencies, for putative major genes or QTLs. There is extreme variation in many traits including weight, speed, behavior patterns, aggression, and hunting methods; this offers a wealth of opportunities for mapping single major loci as well as quantitative trait loci.

Among dog breeders and dog owners there is great concern about inherited diseases, particularly those with a simple recessive 
Table 2. 16 linkage groups defined by typing of the reference panel of the international DogMap collaboration.

\begin{tabular}{|c|c|c|c|c|}
\hline $\begin{array}{l}\text { Linkage } \\
\text { group }\end{array}$ & locus 1 & locus 2 & $\begin{array}{l}\text { Recombination } \\
\text { fraction }\end{array}$ & $\begin{array}{l}\text { lod } \\
\text { score }\end{array}$ \\
\hline \multirow[t]{7}{*}{ LI } & \multirow[t]{4}{*}{ AHT 125} & AHT 118 & 0,021 & 10.54 \\
\hline & & 2010 & 0.133 & 9.94 \\
\hline & & 363 & 0.071 & 9.32 \\
\hline & & CXX.130 & 0.150 & 9.04 \\
\hline & \multirow[t]{2}{*}{ AHT 118} & 2010 & 0.159 & 3.24 \\
\hline & & 363 & 0.001 & 6.62 \\
\hline & 2010 & 363 & 0.155 & 4.03 \\
\hline \multirow[t]{3}{*}{$\mathrm{L} 2$} & \multirow[t]{2}{*}{ LEI 024} & LEI 025 & 0.058 & 9.17 \\
\hline & & CPH 8 & 0.111 & 5.94 \\
\hline & LEI 025 & CPH 8 & 0.021 & 10.83 \\
\hline \multirow[t]{6}{*}{ L3 } & \multirow[t]{3}{*}{ AHT 109} & LEI 030 & 0.178 & 3.58 \\
\hline & & CXX.69 & 0.078 & 5.64 \\
\hline & & СPH 3 & 0.073 & 6.48 \\
\hline & \multirow[t]{2}{*}{ LEI 030} & CXX.69 & 0.051 & 9.60 \\
\hline & & CPH 3 & 0.122 & 8.30 \\
\hline & CXX.69 & CPH 3 & 0.016 & 14.31 \\
\hline $\mathrm{L} 4$ & AHT 135 & LEI 004 & 0.054 & 19.05 \\
\hline \multirow[t]{4}{*}{ L5 } & \multirow[t]{2}{*}{$\mathrm{TF}$} & 453 & 0.030 & 13.27 \\
\hline & & CXX.123 & 0.048 & 7.65 \\
\hline & \multirow[t]{2}{*}{453} & CXX.123 & 0.018 & 9.56 \\
\hline & & CPH 6 & 0.100 & 7.53 \\
\hline L6 & PI1 & 618 & 0.039 & 5.38 \\
\hline $\mathrm{L} 7$ & LEI 005 & CXX.279 & 0.056 & 23.34 \\
\hline \multirow[t]{3}{*}{ L8 } & \multirow[t]{2}{*}{ LEI 032} & CXX.213 & 0.218 & 3.54 \\
\hline & & AHTk120 & 0.185 & 3.45 \\
\hline & CXX.213 & AHTk120 & 0.083 & 8.18 \\
\hline L9 & LEI 001 & CXX.20 & 0.145 & 4.82 \\
\hline L.10 & AHT 133 & CXX.359 & 0.070 & 8.99 \\
\hline L.11 & CPH 11 & $\mathrm{CPH} 1$ & 0.001 & 5.12 \\
\hline \multirow[t]{2}{*}{ L12 } & \multirow[t]{2}{*}{ CPH 9} & CXX.188 & 0.100 & 3.89 \\
\hline & & CXX.2 & 0.065 & 6.93 \\
\hline \multirow[t]{2}{*}{ L13 } & \multirow[t]{2}{*}{630} & СРH 16 & 0.122 & 4.07 \\
\hline & & AHTk20 & 0.085 & 8.22 \\
\hline L14 & AHT127 & CPH 13 & 0.069 & 10.13 \\
\hline L15 & VIAS-D10 & CPH 20 & 0.083 & 3.63 \\
\hline L16 & AHTk 292 & AHTk32 & 0.077 & 3.86 \\
\hline
\end{tabular}

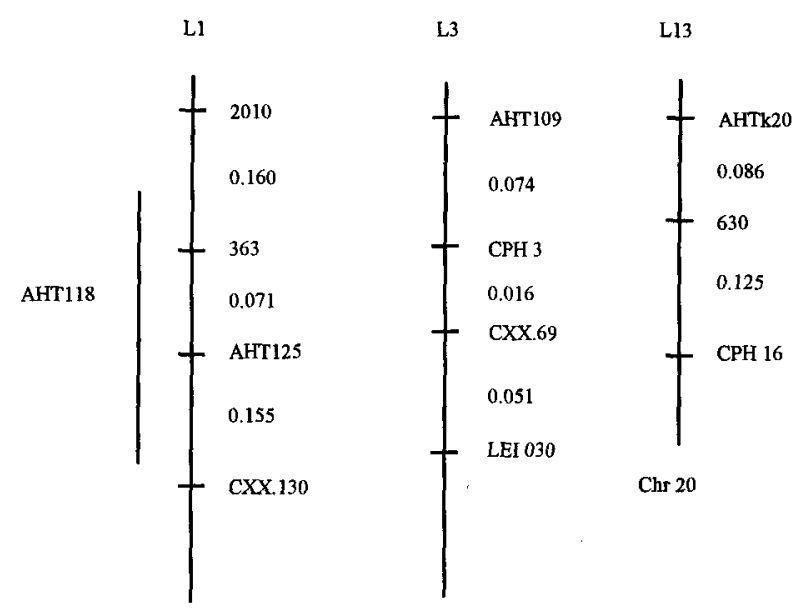

Fig. 2. Ordering of the linkage groups L1, L3, and L13. Linkage group 1 was established by ordering 2010-AHT125-CXX.130 using ILINK (odds $1.67 \mathrm{E}+3$ ) and integrating 363 with LINKMAP (odds 7.41E + 3). The locus AHT118 cannot be placed properly with LINKMAP but lies between 2010 (odds $5.59 \mathrm{E}+5$ ) and CXX.130 (odds $2.55 \mathrm{E}+3$ ). Linkage group 3 was established by placing LEI 030 relative to AHT109-CXX.069 with LINKMAP (odds $1.01 \mathrm{E}+3$ ) and integrating CPH 3 with LINKMAP (odds $9.20 \mathrm{E}+2$ ). Linkage group 13 was established by placing AHTk20 relative to 630-CPH 16 (odds 2.18E + 4). AHTk20 anchors L13 on Chr 20 (Chr 20 ). The distances indicated are given in Kosambi morgans and based on two-point linkage analysis. mode of inheritance, which are the most numerous. The frequency of inherited diseases is alarmingly high in many dog breeds, and these disorders have proved difficult to eradicate by traditional breeding methods. The diagnosis of an inherited disease in a litter usually results in the exclusion of close relatives from further breeding. This may have a dramatic impact on effective population sizes, especially in small inbred populations, and may also reduce breeding progress for other important traits. The identification of genes involved in frequently occurring inherited diseases will allow breeders to avoid crossing two dogs that are carriers for the same recessive disorder. This will have an immediate, dramatic impact on the frequency of dogs suffering from inherited diseases. At the same time, genetic testing permits breeders to do carrier $x$ normal crosses to maintain and improve other beneficial traits in their lines. Mating such carrier males with females homozygous negative for the disease will not produce animals with the disease, and selection against carriers of disease alleles may be performed in the next generation. The existence of canine homologs of human inherited diseases offers attractive possibilities for the development and testing of treatments for human inherited diseases in these canine disease models.

Acknowledgments. Work at the Animal Health Trust and University of Leicester was supported by the Guide Dogs for the Blind Association. Work at the Norwegian College of Veterinary Medicine, the Royal Veterinary and Agricultural University, Denmark, and the Swedish University of Agricultural Sciences was supported by the Nordic Ministry of Agriculture.

\section{References}

Baur EW, Schorr RT (1969) Genetic polymorphism of tetrazolium oxidase in dogs. Science 166, 1524-1525

Cottingham RW Jr, Idury RM, Schaffer AA (1993) Faster sequential genetic linkage computations. Am J Hum Genet 53, 252-263

Fischer PE, Holmes NG, Dickens HF, Thomas R, Binns MM, Nacheva EP (1996) The application of FISH techniques for physical mapping in the dog (Canis familiaris). Mamm Genome 7, 37-41

Francisco LV, Langston AA, Mellersh CS, Neal CL, Ostrander EA (1996) A class of highly polymorphic tetranucleotide repeats for canine genetic mapping. Mamm Genome 7, 359-362

Fredholm M, Winterø AK (1995) Variation of short tandem repeats within and between species belonging to the Canidae family. Mamm Genome $6,11-18$

Holmes NG, Mellersh CS, Humphreys SJ, Binns MM, Holliman A, Curtis R, Sampson J (1993a) Isolation and characterization of microsatellites from the canine genome. Anim Genet 24, 289-292

Holmes NG, Humphreys SJ, Binns MM, Curtis R, Holliman A, Scott AM (1993b) Characterization of canine microsatellites. In DNA Fingerprinting: State of the Science, S.D.J. Pena, R. Chakraborty, J.T. Epplen, A.J. Jeffreys, eds. (Basel, Switzerland: Birkhauser Verlag) pp 415-420

Holmes NG, Strange NJ, Binns MM, Mellersh CS, Sampson J (1994) Three polymorphic canine microsatellites. Anim Genet 25, 200

Holmes NG, Dickens HF, Parker HL, Binns MM, Mellersh CS, Sampson J (1995) Eighteen canine microsatellites. Anim Genet 26, 132-133

Juneja RK, Arnold ICJ, Gahne B, Bouw J (1987) Parentage testing of dogs using variants of blood proteins: description of five new plasma protein polymorphisms. Anim Genet 18, 297-310

Juneja RK, Gahne B, Lukka M, Ehnholm C (1989) A previously reported polymorphic plasma protein of dogs and horses, identified as apolipoprotein A-IV. Anim Genet 20, 59-63

Mellersh C, Holmes N, Binns M, Sampson J (1994) Dinucleotide repeat polymorphisms at four canine loci (LEI 003, LEI 007, LEI 008 and LEI 015). Anim Genet 25, 125

Ostrander EA, Sprague Jr GF, Rine J (1993) Identification and characterization of dinucleotide repeat $(\mathrm{CA})_{\mathrm{n}}$ markers for genetic mapping in dog. Genomics 16, 207-213 
Ostrander EA, Mapa FA, Yee M, Rine J (1995) One hundred and one new simple sequence repeat-based markers for the canine genome. Mamm Genome 6, 192-195

Primmer CR, Matthews ME (1993) Canine tetranucleotide repeat polymorphism at the VIAS-D10 locus. Anim Genet, 24, 332

Shibuya H, Collins BK, Huang TH-M, Johnson GS (1994) A polymorphic (AGGAAT)n tandem repeat in an intron of the canine von Willebrand factor gene. Anim Genet 25, 122
Świtoński M, Reimann N, Bosma AA, Long S, Bartnitzke S, Pieńkowska A, Moreno-Milan MM, Fischer P (1996) Report on the progress of standardization of the G-banded canine (Canis familiaris) karyotype. Chromosome Res 4, 306-309

Yuzbasiyan-Gurkan V, Blanton SH, Cao Y, Ferguson P, Li J, Venta PJ, Brewer GJ (1996) Linkage of a microsatellite marker to the canine copper toxicosis locus in the Bedlington Terrier. Am J Vet Res in press 